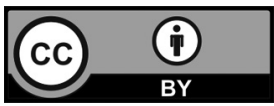

\title{
DEVELOPMENT OF SEMEN QUALITY IN MALE PARTNERS OF INFERTILE COUPLES IN THE REPUBLIC OF MOLDOVA
}

\author{
Stela RACOVITA ${ }^{1}$, Mariana SPRINCEAN ${ }^{1}$, Dumitru PONEATENCO ${ }^{2}$, Eusebiu Vlad GORDUZA ${ }^{3}$, \\ Veaceslav MOSIN ${ }^{1,2}$ \\ ${ }^{1}$ Nicolae Testemitanu State University of Medicine and Pharmacy of the Republic of Moldova \\ ${ }^{2}$ Repromed Health Center, Chisinau, Republic of Moldova \\ ${ }^{3}$ University of Medicine and Pharmacy Grigore T. Popa Iasi, Romania
}

Corresponding author: Stela Racovita, e-mail: guzunstela@gmail.com

DOI: $10.5281 /$ zenodo.3701047

UDC: $616.69-008.6(478)$

Key words: human semen, male infertility, diagnosis, reference values.

Introduction. It is estimated that over 15\% of couples of reproductive age face infertility worldwide. In about half of these cases the male factor is involved. To assess the potential of male fertility the spermiogram analysis may not always be an optimal diagnostic tool, but it remains the basic clinical tool.

Material and methods. The purpose of the study is to analyze the regional tendencies of the semen quality in male partners of couples facing infertility. A retrospective study of 4625 patients subject to semen analysis between 2012-2018 was conducted. All semen samples were collected after a recommended period of sexual abstinence of three to five days. The spermiogram analysis was performed by the computerized method according to WHO guidelines for Human Semen analysis, 2010.

Results. Of the total number of 4625 men examined, 1861 (40.2\%) presented normal values of semen - normozoospermia, and 2764 (59.8\%) showed abnormal semen parameters. Asthenozoospermia was the most common abnormality profile recorded in 1394 (30.2\%) men, followed by oligoasthenozoospermia diagnosed in 973 men (21.0\%). Azoospermia was found in 200 men with an estimated prevalence of 4.3\%. In 113 men examined, oligozoospermia was found in 2.4\%. Oligoasthenoteratozoospermia was diagnosed in $1.5 \%$ and necrozoospermia in $0.3 \%$.

Conclusion. The study provides the first evidence that semen quality in men in the Republic of Moldova who are facing infertility in couples has deteriorated over the years.

Cuvinte cheie: material seminal, infertilitate masculină, diagnostic, valori de referință.

\section{EVOLUȚIA CALITĂȚII MATERIALULUI SEMINAL LA BĂRBAȚII PARTENERI DIN CUPLURILE INFERTILE ÎN REPUBLICA MOLDOVA}

Introducere. La nivel mondial se estimează că peste 15\% dintre cuplurile de vârstă reproductivă se confruntă cu infertilitatea, iar în aproximativ jumătate din aceste cazuri este implicat factorul masculin. Pentru evaluarea potențialului de fertilitate masculină spermograma poate să nu fie întotdeauna un instrument de diagnostic optim, cu toate acestea însă rămâne în continuare instrumentul clinic de bază.

Material și metode. Scopul: analiza tendințelor regionale ale calității materialului seminal la bărbații din cadrul cuplurilor ce se confruntă cu infertilitatea. Studiu retrospectiv a fost efectuat în perioada 2012-2018 pe un eșantion de 4625 bărbați care au făcut analize ale materialului seminal. Recoltarea probelor a fost făcută după abstinență de la ejaculare timp de 3-5 zile în condiții de laborator. Spermograma s-a realizat prin metoda computerizată conform criteriilor și valorilor de referință stabilite de OMS în anul 2010.

Rezultate. Din numărul total de 4625 de bărbați investigați, 1861 (40,2\%) au prezentat valori normale ale materialului seminal normozoospermie și 2764 (59,8\%) au prezentat tulburări de spermatogeneză. Cea mai frecventă anomalie a spermatogenezei a fost înregistrată astenozoospermia - la 1394 de bărbați cu o frecvență de 30,2\%, urmată de oligoastenozoospermia - la 973 de bărbați în 21,0\% din cazuri. La 200 de bărbați a fost înregistrată azoospermia, frecvența fiind de 4,3\%, iar la 113 bărbați investigați a fost depistată oligozoospermia cu frecvența de 2,4\%, oligoastenoteratozoospermia - în 1,5\% și necrozoospermia - în 0,3\%.

Concluzii. Studiul confirmă, că calitatea materialului seminal a bărbaților din Republica Moldova, care se confruntă cu infertilitatea în cuplu, se deteriorează de-a lungul anilor. 


\section{INTRODUCTION}

Infertility affects an estimated rate of $15 \%$ of couples of reproductive age worldwide, and in about half of these cases the male factor is involved (1).

The causes of infertility can be divided into four broad categories: 1) female factor; 2) male factor; 3 ) couple factor - due to cumulative female and male infertility; 4) idiopathic infertility, unexplained. The exact percentage for each of these categories is difficult to determine; however, it is generally reported that in about $40 \%$ of cases infertility is due to female cause, in $40 \%$ - male cause, and in $20 \%$ - anomalies detected in both partners $(1,2)$. Thus, the examination of the male partner is as important as the female one for the assessment of couple's fertility. Medical history and physical examination are standard assessments for all men, including semen analysis.

The spermiogram evaluation is relevant for the appreciation of the functional status of the seminiferous tubules, epididymis, and accessory sex glands. The prognostic value of semen characteristics, such as sperm concentration, percentage of motility, and morphology represents the first line of examination in the diagnosis of male infertility (3). Semen analysis may not always be an optimal diagnostic tool, but it still remains the basic clinical tool for the evaluation of male fertility potential (4).

Important treatment decisions in male infertility are largely based on spermiogram results. There- fore, it is essential that the human semen analysis be performed according to the updated requirements of the World Health Organization (WHO), 2010 (5). In recent years, the European Society for Human Reproduction and Embryo-logy (ESHRE), in collaboration with the WHO, have developed a program to improve laboratory standardization in terms of sperm sample diagnosis and assessment criteria (6).

\section{MATERIAL AND METHODS}

The purpose of the study is to analyze the regional tendencies of semen quality in male partners of couples facing infertility.

The study presents a retrospective evaluation of 4625 patients in the Republic of Moldova subject to semen analysis during 2012-2018. All semen samples were collected in laboratory conditions after a recommended period of sexual abstinence of three to five days. Each sample was incubated at $37^{\circ} \mathrm{C}$ and analyzed within an hour. The spermiogram analysis was performed by the computerized method on the automated analyzer SQA IIC-P (Medical Electronic Systems, USA). Semen analysis was performed according to the WHO Laboratory Manual for the Examination and Processing of Human Semen, 5th edition, 2010 (tab. 1). All patients are part of infertile couples who made appointments for doctor`s consultation in the Repromed Center.

Table 1. Semen parameters and reference values according to WHO (2010).

\begin{tabular}{|c|c|}
\hline Abstinence (days) & 3-7 days \\
\hline Volume $(\mathrm{mL})$ & $\geq 1.5 \mathrm{~mL}$ \\
\hline Color & $\leq 2 \mathrm{~cm}$ \\
\hline Liquefaction time & $\leq 60 \min$ \\
\hline Viscosity & $2 \mathrm{~cm}$ \\
\hline $\mathrm{pH}$ & $\geq 7.2$ \\
\hline Leukocytes & $\leq 1 \mathrm{mln} / \mathrm{mL}$ \\
\hline Sperm Concentration $(\mathrm{mln} / \mathrm{mL})$ & $\geq 1.5 \mathrm{~mL}$ \\
\hline Total number of spermatozoa (mln/ejaculate) & $\geq 39 \mathrm{mln}$ \\
\hline Progressives sperm motility (\%) & $\geq 32 \%$ \\
\hline Concentration of motile spermatozoa $(\mathrm{mln} / \mathrm{mL})$ & $\geq 10 \mathrm{mln} / \mathrm{mL}$ \\
\hline Total number of motile spermatozoa (mln/ejaculate) & $\geq 15 \mathrm{mln}$ \\
\hline Concentration of functional spermatozoa $(\mathrm{mln} / \mathrm{mL})$ & $\geq 7 \mathrm{mln} / \mathrm{mL}$ \\
\hline Total number of functional spermatozoa (mln/ejaculate) & $\geq 10.5 \mathrm{mln} / \mathrm{mL}$ \\
\hline Motility index & $\geq 80$ \\
\hline Morphology (Normal forms) (\%) & $\geq 4 \%$ \\
\hline Vitality $(9 \%)$ & $\geq 58$ \\
\hline
\end{tabular}


Interpreting the results, the spermiogram diagnosis was made according to the descriptive terminology of the same WHO guidelines as follows:

- normozoospermia: total number/percentage of sperm with progressive mobility and normal morphology, being of equal value or above the reference values;

- oligozoospermia: total number of sperm/sperm concentration below lower reference limit;

- asthenozoospermia: sperm motility below $40 \%$ or rapid progressive sperm motility $<32 \%$;

- teratozoospermia: percentage of normal sperm below 4\%;

- oligoasthenozoospermia: low concentration and low percentage of progressively motile sperm;

- oligoteratozoospermia: low total number of sperm and low percentage of normal forms;

- asthenoteratozoospermia: percentage of motile sperm and normal sperm below low reference limit;

- oligoasthenoteratozoospermia: low total number of sperm/low percentage of motile sperm and normal forms;

- cryptozoospermia: very low spermatozoa concentration in ejaculate $\leq 1$ million $/ \mathrm{mL}$;

- hypospermia: semen volume $<1,5 \mathrm{~mL}$;
- hyperspermia: semen volume $>1,5 \mathrm{~mL}$;

- leukospermia/pyospermia: presence of leukocytes in ejaculate above reference limit;

- hematospermia: presence of blood in ejaculate; - necrozoospermia: low percentage of live and high percentage of immotile sperm;

- aspermia: complete lack of semen with ejaculation;

- azoospermia: absence of spermatozoa in the sediment of a centrifuged semen sample.

\section{RESULTS}

In the biology laboratory of the Repromed Center, Chisinau, Republic of Moldova, the spermiogram was performed in 4625 men, during 2012-2018. The Repromed Center is an Assisted Reproduction Center where the vast majority of infertility couples from all over the country present themselves. Spermiograms were performed over the following years: 2012 - 206 patients, 2013 - 702 patients, 2014 - 854 patients, 2015 - 800 patients, 2016 717 patients, $2017-703$ patients, and $2018-643$ patients. The number of semen analyses in the studied period is relatively constant. Except for 2012, because patients were registered since the middle part of the year since the Repromed Center started activity (tab. 2).

Table 2. Distribution of men according to their semen characteristics in the period 2012-2018 in the Republic of Moldova.

\begin{tabular}{lccccccccc}
\hline \multicolumn{1}{c}{ Semen parameters } & \multicolumn{1}{c}{ Absolute number } \\
\cline { 2 - 11 } & $\mathbf{2 0 1 2}$ & $\mathbf{2 0 1 3}$ & $\mathbf{2 0 1 4}$ & $\mathbf{2 0 1 5}$ & $\mathbf{2 0 1 6}$ & $\mathbf{2 0 1 7}$ & $\mathbf{2 0 1 8}$ & Total & \% \\
\hline Normozoospermia & 103 & 358 & 348 & 340 & 260 & 235 & 217 & $\mathbf{1 8 6 1}$ & 40.2 \\
\hline Oligozoospermia & 13 & 24 & 26 & 16 & 18 & 10 & 6 & $\mathbf{1 1 3}$ & 2.4 \\
\hline Oligoasthenozoospermia & 27 & 90 & 166 & 173 & 165 & 170 & 182 & $\mathbf{9 7 3}$ & 21.0 \\
\hline Asthenozoospermia & 44 & 179 & 245 & 231 & 235 & 250 & 210 & $\mathbf{1 3 9 4}$ & 30.2 \\
\hline Oligoasthenoteratozoospermia & 5 & 13 & 11 & 12 & 11 & 13 & 3 & $\mathbf{6 8}$ & 1.5 \\
\hline Necrozoospermia & & 6 & 6 & & 3 & & 1 & $\mathbf{1 6}$ & 0.3 \\
\hline Azoospermia & 14 & 32 & 52 & 28 & 25 & 25 & 24 & $\mathbf{2 0 0}$ & 4.3 \\
\hline Total & $\mathbf{2 0 6}$ & $\mathbf{7 0 2}$ & $\mathbf{8 5 4}$ & $\mathbf{8 0 0}$ & $\mathbf{7 1 7}$ & $\mathbf{7 0 3}$ & $\mathbf{6 4 3}$ & $\mathbf{4 6 2 5}$ & $\mathbf{1 0 0}$ \\
\hline
\end{tabular}

Of the total number of 4625 men examined, 1861 $(40.2 \%)$ presented normal values of semen - normozoospermia, 2764 (59.8\%) showed abnormal semen parameters. The most common profile of abnormality recorded in our study was asthenozoospermia in 1394 men from 2012 to 2018 with a frequency of $30.2 \%$, followed by oligoasthenozoospermia being diagnosed in 973 men $-21.0 \%$. Azoospermia was recorded in 200 men with an estimated prevalence of $4.3 \%$. In 113 men examined, the frequency of oligozoospermia accounted for $2.4 \%$. In 113 men examined, oligozoospermia was detected in $2.4 \%$. Oligoasthenoteratozoospermia was diagnosed in 68 men $(1.5 \%)$ and necroszoospermia in 16 men $(0.3 \%)$ (tab. 2, fig. 1 ).

Normozoospermia was considered according to the following WHO criteria: sperm concentration $\geq 1.5 \mathrm{mln} / \mathrm{mL}$, total number of sperm cells $\geq 39$ mln, progressive sperm motility $\geq 32 \%$ and morphology $\geq 4 \%$. The results of normozoospermia analysis were recorded in 2012 and 2013 with a 
frequency of 50.9\%. In 2014, the normal values of spermiogram decreased by $10.2 \%$, the frequency accounted for $40.7 \%$. In 2015 the situation improved insignificantly compared to 2014 by $1.8 \%$.
Over the following years a decrease of normal values of spermatogenesis was also observed. In 2016 the frequency accounted for $36.3 \%$, in 2017 $-33.4 \%$, in $2018-33.7 \%$ (fig. 2).

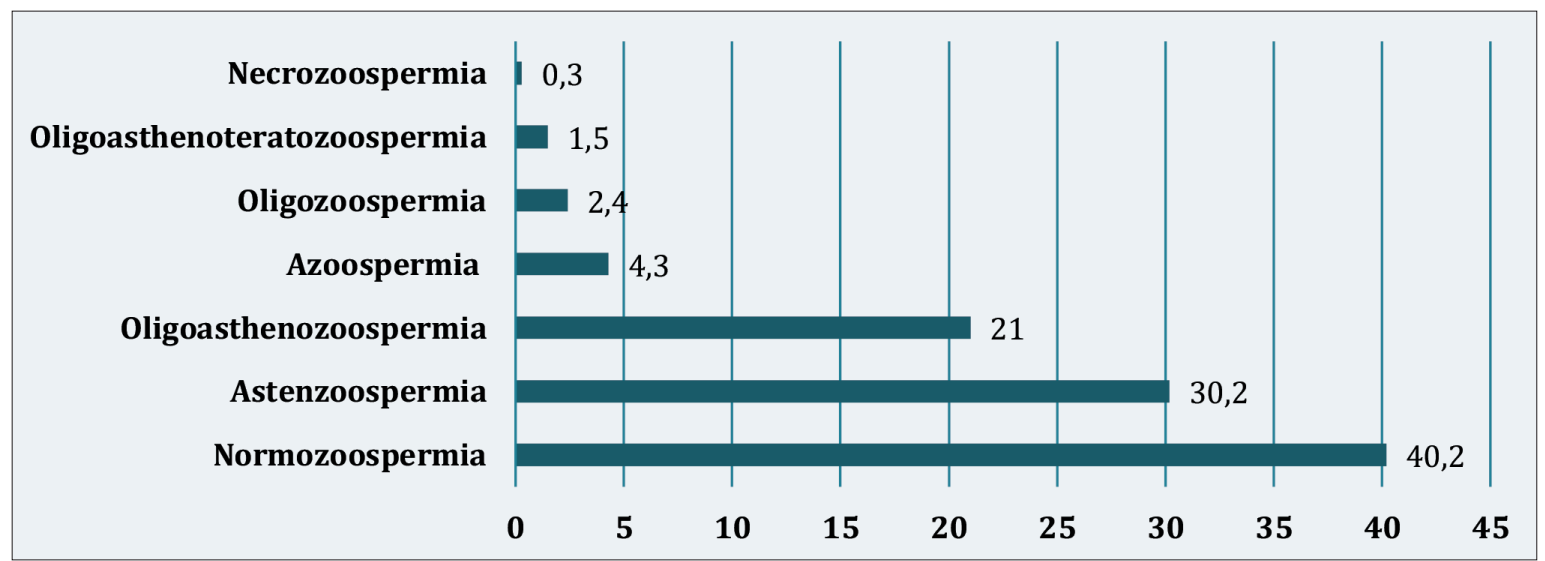

Figure 1. Distribution of patients according to semen analysis during the period 2012-2018.

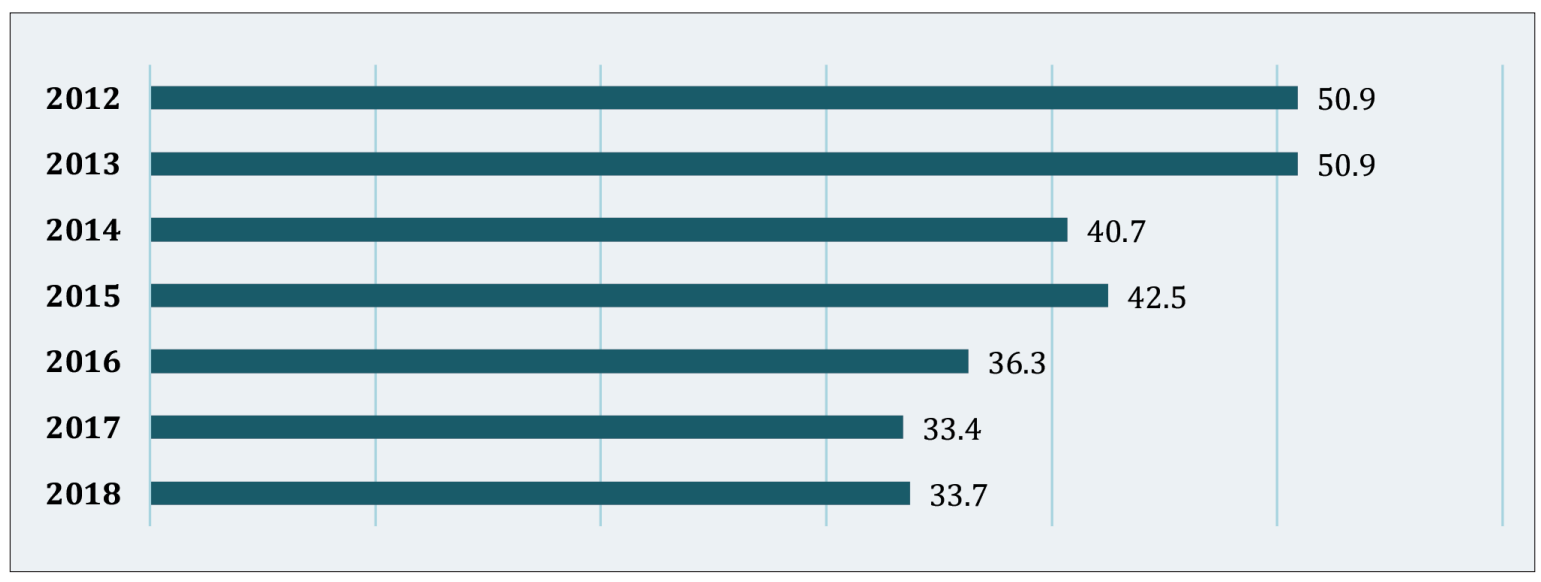

Figure 2. Frequency of normozoospermia in men during 2012-2018.

According to the results of asthenozoospermia analysis in 2012 the frequency was $21.7 \%$. In 2013 the frequency increased by $3.7 \%$ compared to the previous year. Over the following years the values of asthenozoospermia also increased, in $2014-28.6 \%$, in $2015-28.8 \%$, in $2016-32.7 \%$, in $2017-35.5 \%$, and in $2018-32.6 \%$ (fig. 3).

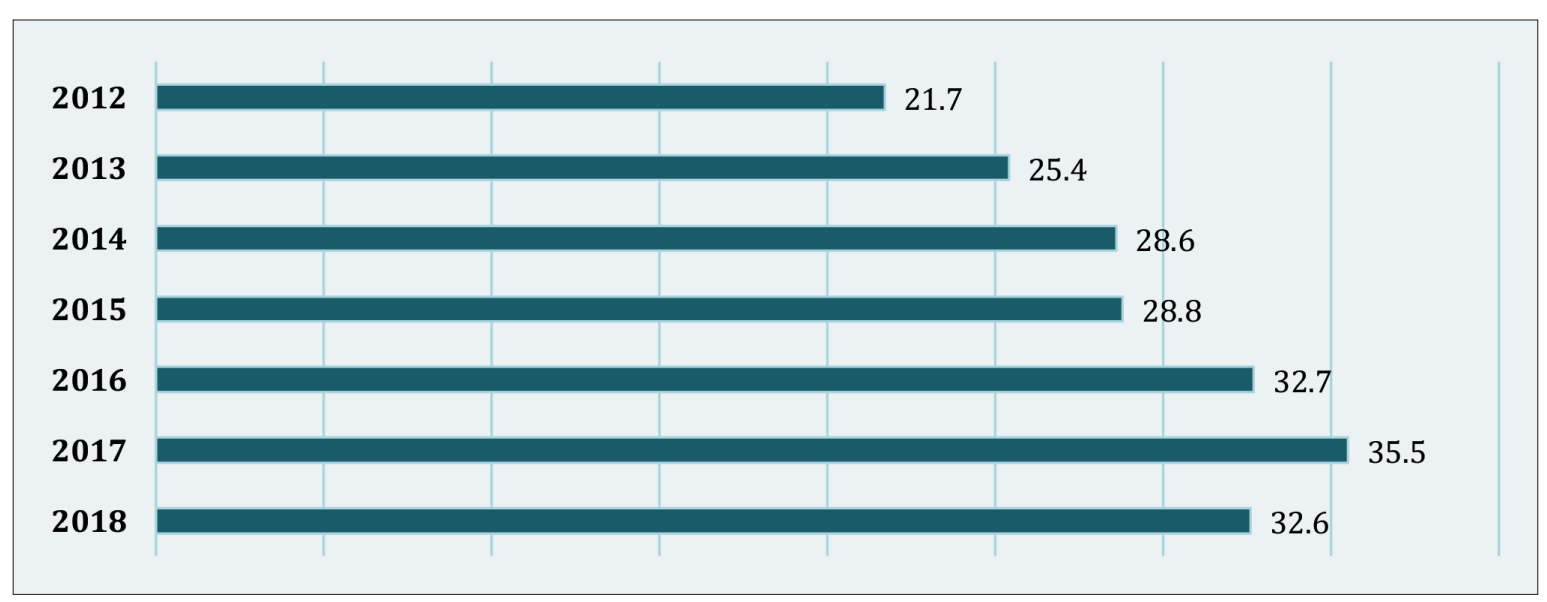

Figure 3. Frequency of men with asthenozoospermia during 2012-2018. 


\section{DISCUSSIONS}

The study shows that during 2012-2018, the abnormal semen quality was found in approximately $59.8 \%$ of male partners of couples facing infertility (tab. 2). A high incidence of spermatogenic disorders is also found in other studies $(7,8,9)$ According to our data, this percentage increased from $50 \%$ in 2012 to $66.3 \%$ in 2018 (tab. 2).

This represents a significant increase in spermatogenesis abnormalities, although the WHO introduced lower baseline values in 2010. Thus, an alarming phenomenon of decreased male fertility can be observed in fertility clinics in the Republic of Moldova, which could be correlated with sperm decline described in the literature. This has been illustrated by several studies from multiple world regions that argue that men's reproductive health has been in rapid decline in the recent years $(10,11)$.

In the present study we observe that sperm concentration in the semen and healthy sperm count have decreased considerably. If in 2012 and 2013 the frequency of normozoospermia was $50.9 \%$, over the following years a decrease in the normal values of spermatogenesis could be observed, accounting for $33.7 \%$ in 2018 (fig. 2).

The most common profile of abnormality in our study was asthenozoospermia recorded in 1394 men with a frequency of $30.2 \%$ (fig. 1). It is very noticeable that the abnormal frequency of sperm motility increased from 2012 to 2018. Thus, in 2012 the frequency of asthenozoospermia was $21.7 \%$, in $2014-28.6 \%$ it increased, in $2015-$ $28.8 \%, 2016-32.7 \%$, in 2017 - 35.5\%. In 2018 there was a slight decrease of asthenozoospermia - 32.6\%, most probably due to a lower number of appointments of couples with infertility compared to the previous year (fig. 3). According to literature data, this abnormality is found in $40 \%$ of men, affecting their fertility. The role of socio-psycho-behavioral factors in the development of this abnormality has been demonstrated. Psychological stress, smoking and alcohol are modifiable risk factors for the number of motile sperm (12). Also, sperm motility depends on its specific structures such as microtubules, outer dense fibers and mitochondria that provide energy for sperm movements (13).

The second cause of spermatogenesis disorder identified in our study was oligoastenozoospermia with a frequency of $21.0 \%$. Oligoastenozoospermia is a combination of reduced sperm motility and low sperm count. According to bibliographic sources it is the most common cause of male infertility (14). The causes of this disorder are heterogeneous, such as cryptorhidia, varicocele, chronic infections, hormonal causes, psychoemotional causes, metabolic causes, etc. In $20 \%$ its etiology and pathogenesis are not fully elucidated and may be associated with specific gene abnormalities (13).

The frequency of azoospermia in the current study accounts for $4.3 \%$. According to bibliographic sources azoospermia is found in $8 \%$ of infertile men and in $1 \%$ of the male population (15). In the case of lack of sperm or an extremely small number, a genetic cause may be identified in about $21-29 \%$ (16). In this context, cytogenetic tests for karyotype analysis as well as molecular genetic evaluation of Y-chromosome microdeletions analysis and mutations in the Cystic Fibrosis Transmembrane Conductance Regulator (CFTR) gene are fully justified and important to exclude a possible cause of genetic origin. Abnormal genotype may be present in up to $12 \%$ of azoospermic men and $4 \%$ of oligospermic men. Cystic fibrosis screening is recommended for azoospermia if it is due to congenital bilateral absence of the vas deferens (CBAVD). Optional Y-chromosome microdeletion screening can be carried out if sperm count is $<5$ million $/ \mathrm{mL}$.

\section{CONCLUSION}

1. Our results clearly show that semen quality in the population of men in couples with infertility in the Republic of Moldova decreased from 2012 to 2018. As many authors suggest, we also believe that environmental and lifestyle factors have negatively affected the quality of semen development. The contribution of genetic factors cannot be excluded either.

2. Therefore, the analysis of the regional tendencies of semen quality is necessary and can be considered an indirect factor in assessing the tendencies in male infertility.

\section{CONFLICT OF INTEREST}

No conflict of interest was declared by the authors. 


\section{REFERENCES}

1. Agarwal A, Mulgund A, Hamada A, Chyatte MR. A unique view on male infertility around the globe. Reprod Biol Endocrinol. 2015;13(1).

2. Esteves SC, Zini A, Aziz N, Alvarez JG, Sabanegh ES, Agarwal A. Critical appraisal of world health organization's new reference values for human semen characteristics and effect on diagnosis and treatment of subfertile men. Urology. 2012; 79(1):16-22.

3. Huyghe E, Izard V, Rigot JM, Pariente JL, Tostain J. Évaluation de l'homme infertile: recommandations AFU 2007. Prog en Urol. 2008; 18(2):95-101.

4. Gill K, Jakubik J, Rosiak-Gill A, Kups M, Lukaszuk M, Kurpisz M, et al. Utility and predictive value of human standard semen parameters and sperm dna dispersion for fertility potential. Int J Environ Res Public Health. 2019; 16(11).

5. World Health Organization. Department of Reproductive Health and Research. WHO Laboratory Manual for the Examination and Processing of Human Semen. 5th ed. Geneva: World Health Organization; 2010; (1)-287.

6. Cooper TG, Noonan E, von Eckardstein S, Auger J, Baker HWG, Behre HM, et al. World Health Organization reference values for human semen characteristics. Hum Reprod Update. 2009; 16(3):231-45.

7. Niang L, Ndoye M, Labou I, Jalloh M, Kane R, Diaw JJ, et al. Profil épidémiologique et clinique de l'infertilité masculine à l'hôpital général de Grand-Yoff, Sénégal: à propos de 492 cas. Andrologie. 2009; 19(2):103-7.

8. Owolabi AT, Fasubaa OB, Ogunniyi SO. Semen quality of male partners of infertile couples in Ile-Ife, Nigeria. Niger J Clin Pract. 2013; 16(1):37-40.

Date of receipt of the manuscript: 15/12/2019

Date of acceptance for publication: 31/01/2020

Stela RACOVITA, ORCID 0000-0002-0900-0096
9. Basnet P, Hansen SA, Olaussen IK, Hentemann MA, Acharya G. Changes in the semen quality among 5739 men seeking infertility treatment in Northern Norway over past 20 years (1993-2012). Journal of Reproductive Biotechnology and Fertility. 2016; 5:1-7.

10. Geoffroy-Siraudin C, Dieudonné Loundou A, Romain $\mathrm{F}$, Achard V, Courbière B, Perrard MH, et al. Decline of semen quality among 10932 males consulting for couple infertility over a 20-year period in Marseille, France. Asian J Androl. 2012; 14(4):584-90.

11. Louis JF, Thoma ME, Sorensen DN, Mclain AC, King RB, Sundaram R, et al. The prevalence of couple infertility in the United States from a male perspective: Evidence from a nationally representative sample. Andrology. 2013; 1(5):741-8.

12. Li Y, Lin H, Li Y, Cao J. Association between socio-psycho-behavioral factors and male semen quality: Systematic review and meta-analyses. Fertil Steril. 2011; 95(1):116-23.

13. Gupta Sanjay, Swapnil S. Singhai. Management of oligoasthenozoospermia: an observational clinical study. European Journal of Pharmaceutical and Medical Research, 2016; 3(6):387-90.

14. Punab M, Poolamets O, Paju P, et al. Causes of male infertility: a 9 - year prospective monocentre study on 1737 patients with reduced total sperm counts. Hum Reprod. 2017; 32(1):18-31.

15. Lee JY, Dada R, Sabanegh E, Carpi A, Agarwal A. Role of genetics in azoospermia. Urology. 2011; 77(3):598-60.

16. Hamada AJ, Esteves SC, Agarwal A. A comprehensive review of genetics and genetic testing in azoospermia. Clinics. 2013; 68 (SUPPL.1):39-60. 